\title{
1. The meanings of regulatory costs
}

Legislation enabling regulators to govern risk characteristically requires, permits, or forbids the consideration of regulation's costs. Even legislative silences on costs raise the issue given how contentious risk regulation has grown. One need not be an economist to appreciate that most good things come at a cost. But economists typically think that everything has a cost - that every opportunity or good in life entails missed opportunities or goods-which can be priced. ${ }^{1}$ So what does enabling legislation mean when it directs a regulator to consider, or perhaps to minimize, the costs of regulation? This chapter argues that the meaning of cost as a consideration in regulation has changed over time and that it stems from a menu of very different ethical and moral grounds.

Despite a steady diet of cases interpreting statutory signals of this kind, the US Supreme Court has established precious few rules. And as the legal philosopher Scott Shapiro has argued, rules in a legal system tend to have a compensatory aim rooted in distrust: affording government officials "a large degree of interpretive discretion ... provides them with opportunities to expand their powers, reduce restrictions, and further increase their discretion beyond the level contemplated by designers." 2 Europe has not fared much better. Regulatory methods vary so widely

1 Of course, many things have no market price. See Martha C. Nussbaum, The Costs of Tragedy: Some Moral Limits of Cost-Benefit Analysis, 29 J. LEGAL STUD. 1005 (2000). But some argue this is merely the outset of a grand progression in favor of pricing more. See, e.g., CASS R. SUNSTEIN, RISK AND REASON: SAFETY, LAW, AND THE ENVIRONMENT (2002). Thus, especially if we take economics as "the study of human behavior as a relationship between given ends and scarce means which have alternative uses," LIONEL ROBBINS, AN ESSAY ON THE NATURE AND SignificANCE OF ECONOMICS 16 (1932), then economic cost is a pervasive-perhaps constitutive-element. See Roger E. Backhouse \& Steve G. Medema, Defining Economics: The Long Road to Acceptance of the Robbins Definition, 76 ECONOMICA 805 (2009).

2 ScotT J. Shapiro, Legality 340 (2011). 
among the two systems ${ }^{3}$ that general bureaucratic norms on the consideration of costs are almost impossible to detect or to evaluate. This chapter outlines a spectrum of statutory and administrative contexts where regulation's costs may, must, or must not matter to risk regulators. The majority of this is what we would call environmental health and safety regulation. But many of the same problems arise in banking and financial regulation, taxation, trade, healthcare, etc. The benefits of risk reduction can come at a cost; perhaps so high a cost that it is deemed prohibitive. Whatever they come to ultimately, though, regulation's costs have always been a kind of countervailing consideration and, thus, a reason to temper, to delay, or to reject some regulatory action all things considered. As the monograph explores in detail, a great deal turns on how those costs are estimated and evaluated. But this chapter first introduces the socioeconomic and political — the legislative — contexts in which the questions arise.

\subsection{COSTS AS CONSIDERATION IN RISK REGULATION-A “FACTOR” WITHOUT FOUNDATIONS}

For as long as we have thought of legislation as a means to social ends, it has sent conflicting signals: embodied distinct, often competing purposes joined in compromise. ${ }^{4}$ Courts and agencies, thus, sort delegative statutes into those that require fixed decisional procedures, those that allow a freer kind of aggregative "factoring" of different purposes or goals, and still other types of delegation less recognizably common. ${ }^{5}$ For example, most of the environmental legislation in the United States of the 1970s was reasonably clear that Congress wanted its chief implementing agent, the Environmental Protection Agency (EPA), to consider the costs of its air and water pollution (and other risk) regulations. Nonetheless, overt statutory ambiguities engulfed how, when, and why such costs should be tabulated and considered. Research into the legislative histories of those statutes has repeatedly confirmed that these ambiguities were no

3 See Jonathan B. Wiener, The Real Pattern of Precaution, in THE REALITY of Precaution: Comparing Risk Regulation in the United States AND EuROPE 519 (Jonathan B. Wiener et al. eds., 2011).

4 See Jeremy Waldron, The Dignity of Legislation (1999).

5 See Robert A. Katzmann, Judging Statutes 11-22 (2014). 
mere oversight. ${ }^{6}$ So it was often unclear whether the expected costs of a regulation were to be compared to its expected benefits; whether they should just be estimated and considered in some less structured way; or rather that they be used to completely different effect, e.g., to inform later congresses, the public, or still other bureaucratic decision makers. A seemingly interminable debate has dragged on over permitting Congress to "delegate" in this fashion, either as a legal or as a prudential/political matter. ${ }^{7}$ Let us consider why.

A pair of cases construing the Occupational Safety and Health Act of 1970 (OSH Act) underscores precisely how imprecise Congress has usually been in its legislation as well as the troubles that creates. Under the statute, the Occupational Safety and Health Administration (OSHA) was to protect workers from "toxic or harmful physical agents" with standards "which most adequately [assure], to the extent feasible, on the basis of the best available evidence, that no employee will suffer material impairment of health or functional capacity even [from] ... regular exposure to the hazard."8 In short, OSHA's "considerations" were not tightly constrained. ${ }^{9}$

In its rulemaking regulating workplace exposures to benzene, OSHA concluded (as it had in prior rulemakings) that the delegation required it to weigh the costs of technologically attainable reductions of benzene exposure-but not that it must compare the expected benefits and costs of its standard and proceed only if the former outnumbered the latter. ${ }^{10} \mathrm{~A}$ lower court disagreed, ${ }^{11}$ and a divided Supreme Court could not form a majority on what relevance, precisely, costs were to have in reducing workplace exposures to benzene. ${ }^{12}$ The benzene case, as it has been

6 Ambiguity is perhaps the oldest of collective decision-making tools. See Jon Elster, Securities Against Misrule: Juries, Assemblies, Elections (2013).

7 See Thomas W. Merrill, Rethinking Article I, Section 1: From Nondelegation to Exclusive Delegation, 104 COLUM. L. REV. 2097 (2004).

829 U.S.C. $\$ 655($ b) (5).

9 See Public Citizen Health Research Group v. Tyson, 796 F.2d 1479, 1494-96 (D.C. Cir. 1986) (recounting and analyzing OSH Act $\S 6$ and the doctrines construing it).

10 See Occupational Safety and Health Admin., Dept. of Labor, Occupational Exposure to Benzene, 43 Fed. Reg. 5918, 5920, 5934-40 (1978).

11 See American Petro. Inst. v. OSHA, 581 F.2d 493, 503-04 (5th Cir. 1978), rev'd in part sub. nom., Industrial Union Dept., AFL-CIO v. American Petro. Inst., 448 U.S. 607 (1979).

12 See Industrial Union Dept., 448 U.S. at 708-09 \& n.27 (Marshall, J., dissenting) (noting plurality and concurrences' differences in rationale and how 
remembered, remanded OSHA's standard to it with little guidance beyond a vague, conflicted implication that what the agency had done was somehow contrary to law. ${ }^{13}$ So the very next Term a Supreme Court majority waded back into the logjam in a case involving cotton dust, American Textile Mfrs., concluding that the Act did not require a structured cost-benefit criterion. ${ }^{14}$

The cotton dust majority compared several similar statutes and found that together they demonstrated that "Congress uses specific language when intending that an agency engage in cost-benefit analysis," 15 that the OSH Act did not use such language, and that "cost-benefit analysis by OSHA is not required by the statute because feasibility analysis is." 16 It was the mirror image of the Benzene plurality's move-analogizing the OSH Act to other, similar statutes. ${ }^{17}$ This time, though, a majority in

differently they understood the statute, Congress's powers under Article I, and the reviewing courts' functional roles).

13 But see SUNSTEIN, supra note 1 at 195 ("Though the plurality left undecided the question whether the agency must also show a reasonable proportion between costs and benefits, it is clear ... [it] was motivated by the desire to ensure some kind of proportionality between benefits and costs ...").

14 See American Textile Mfrs. Inst. v. Donovan, 452 U.S. 490, 508-09 (1981).

15 Donovan, 452 U.S. at $510-11$.

16 Id. at 509 (emphasis added); see id. at 510-12 \& n.30 (citing the CAA, CWA, Energy Policy and Conservation Act, Consumer Product Safety Act, and others). Courts invoking this discussion in Donovan since have taken "feasible" to mean "technically possible and affordable," City of Portland v. EPA, 507 F.3d 706, 712 (9th Cir. 2007), as requiring the agency to avoid "insuperable financial burdens on the affected industries," Forging Indus. Ass'n v. Secretary of Labor, 773 F.2d 1436, 1453 (4th Cir. 1985), and that the agency demonstrate a "reasonable likelihood that ... costs will not threaten the existence or competitive structure of an industry, even if it does portend disaster for some marginal firms." Public Citizen Health Res. Grp. v. U.S. Dept. of Labor, 557 F.3d 165 (3d Cir. 2009) (quoting United Steelworkers of Amer. v. Marshall, 657 F.2d 1189, 1272 (D.C. Cir. 1980)).

17 The Fifth Circuit in American Petroleum Inst. held that any OSHA standard had to address a "significant" risk and had to make a "significant" reduction in that risk if it were going to impose significant costs of compliance in the process. See 581 F.2d at 499-505. The court helped itself to that interpretation of the OSH Act by analogizing it to what it called the "precisely similar" Consumer Product Safety Act, id. at 502, citing Aqua Slide 'N' Dive Corp. v. CPSC, 569 F.2d 831 (5th Cir. 1978). Justice Stevens seemed to adopt the Fifth Circuit's approach in his plurality opinion, see Industrial Union Dept., 448 U.S. at 414-15, but Justice Rehnquist's vote for the remand did nothing of the kind, leaving Justice Stevens without a majority. 
American Textile Mfrs. unequivocally rejected the cost-benefit interpretation, albeit without clarifying the expected form or content of its so-called "feasibility analysis." Subsequent lower court cases took this "feasibility" approach to have distinct features, most notably the need to examine and evaluate regulatory burdens rather closely. ${ }^{18}$

There are good reasons not to align costs against benefits in some synthetic calculus the elements of which are often so disparate. For one thing, as often as Congress or the European Commission has referenced cost in their risk regulation delegations, they have seldom included anything remotely resembling a mandate for cost-benefit analysis. ${ }^{19}$ For another, syntheses of the kind are only as reliable as their weakest terms. ${ }^{20}$ More importantly, however, the concept of cost itself is deceptively perspectival: a "cost" to one cohort is often mirrored by an equal and opposite benefit to another. The number that represents that cost, on the other hand, conveys nothing of the kind. That essential negotiability has been embodied perhaps most poignantly in the calculation of a "social cost of carbon" (SCC), i.e., climate change damages on a

18 See Sections 2.2 and 2.3.

19 The EU Commission's "Regulatory Scrutiny Board" and "Better Regulation Guidelines" have undergone a rapid evolution from their debut in 2002 as a series of loosely connected, abstract principles into a mandate for "EU policies and laws so that they achieve their objectives at minimum cost." European Commission, Commission Staff Working Document: Better Regulation Guidelines 4 (SWD (2017) 35) (emphasis added), available at https://ec.europa.eu/ info/sites/info/files/better-regulation-guidelines.pdf. $C f$. Alberto Alemanno, How Much Better is Better Regulation?, 6 EUR. L. RISK REG. 344, 350-51 (2015) (arguing that the EU Commission's cost-benefit mandate has the potential to reopen legislative purposes, compromises, and to force new allocations of institutional control throughout the EU). But this shift to cost-benefit analysis of Commission initiatives may be increasingly limited by the lack of interinstitutional consensus regarding such analyses' relevance to final EU directives and regulations. See id. at 351-55.

20 Cf. Adam M. Finkel, The Cost of Nothing Trumps the Value of Everything: The Failure of Regulatory Economics to Keep Pace with Improvements in Quantitative Risk Analysis, 4 Mich. J. ENVTL. \& ADMIN. L. 91, 105 (2014) ("the problem with the weak link in a designed product is not simply the creation of a vulnerability at which the entire product is most likely to fail catastrophically; less well-appreciated is the fact that, in hindsight, all of the time and expense spent on refining the stronger links beyond the quality of the weakest one were wasted."). 
marginal, per-ton basis. ${ }^{21}$ Transforming marginal tons of greenhouse gas (GHG) emissions into a SCC compressed the myriad perspectives, claims, and counterclaims bearing on the risk/regulatory balance at issue into a supposedly singular measure. That quantity, dubbed a cost of not averting emissions, was really just camouflage for the myriad of immensely contestable judgments underlying it. Much as a negotiable instrument embodies all of the possible claims under the law to some underlying asset within a single writing, the SCC estimates purported to do so for each and every single ton of GHG emissions the planet over. That calculation of cost substituted contestability with cardinality, ostensibly in the name of improving analysis. ${ }^{22}$

So how are costs to be assessed and evaluated if not by being done up into a single measure to be leveled against the correlative benefits? A spectrum of answers has emerged from practice, each grounded ultimately in its own ethical footings. ${ }^{23}$ What relevance can be attached to costs when they are not part of a cost-benefit calculus? ${ }^{24}$ Since the OSHA cases it has been abundantly clear that considering regulation's costs is a step which regulators may and do take in various directions. Courts have occasionally interpreted ambiguous statutory directives like

21 See InTERAGENCY WORK GROUP, TeCHNiCAL SupPort DOCUMENT: SOCIAL COST OF CARbON FOR REgUlatory IMPACT ANALYSIS UNDER EXECUTIVE ORDER 12866 (Feb. 2010), available at https://www.epa.gov/sites/ production/files/2016-12/documents/scc_tsd_2010.pdf.

22 It was not so long ago that the conjuring of cardinal measures of welfare from indeterminate collections of diverse individuals, each with their own subjective probabilities and preferences, was immensely controversial. See John C. Harsanyi, Cardinal Welfare, Individualistic Ethics, and Interpersonal Comparisons of Utility, 63(4) J. POL. ECON. 309 (1955).

23 See, e.g., Gregory C. Keating, Pressing Precaution Beyond the Point of Cost-Justification, 56 VAND. L. REV. 653 (2003); David M. Driesen, Distributing the Costs of Environmental, Health, and Safety Protection: The Feasibility Principle, Cost-Benefit Analysis, and Regulatory Reform, 32 B.C. ENVTL. AFFS. L. ReV. 1 (2005); MatThew D. AdLer \& ERIC A. Posner, New Foundations of Cost-Benefit AnAlysis (2006); Richard L. Revesz \& Michael A. Livermore, Retaking Rationality: How Cost-Benefit ANALYSis CAN BetTER PROTECT THE ENVIRONMENT AND OUR HeALTH (2008); Dov Waisman, Equity and Feasibility Regulation, 50 U. RICH. L. REV. 1263 (2016).

24 Even stripping the question of its technical freight and opposing "goods" to "bads" in the simplest sense, the goodness of uncertain prospects can become deceptively complex just in the selection of the proper metrics of "good." See John Broome, WeIghing Goods: Equality, UnCERTAinTy AND Time (1991). When the technical problems of pricing are brought back in, such complexities can easily overtake the value of the analytical exercise itself. 
the one above to require cost-benefit analysis. ${ }^{25}$ And precedents to that effect lie about today ready for the next analogy. ${ }^{26}$ Such a legal mandate, however, puts risk regulators to a task the sense of which remains deeply contested.

Risk regulation's benefits come, if anywhere, in the reduction of risk. That must be some function of identifiable hazards and the means of their containment. ${ }^{27}$ Quantifying this sum has long bedeviled environmental, health, and safety regulators. ${ }^{28}$ This is not least because risk is both a positive (probabilistic) and a normative concept. ${ }^{29}$ To be put at risk

25 A pair of opinions, see Aqua Slide 'N' Dive, 569 F.2d 831; D.D. Bean \& Sons v. CPSC, 574 F.2d 643 (1st Cir. 1978), established a now entrenched judicial construction of the Consumer Product Safety Act's mandate to the Consumer Product Safety Commission that CPSC prepare a cost-benefit analysis for any of its product safety measures. See Zen Magnets LLC v. CPSC, 841 F.3d 1141, 1147-48 (10th Cir. 2016).

26 See, e.g., Business Roundtable v. SEC, 647 F.3d 1144, 1148-52 (D.C. Cir. 2011) (construing Investment Company Act requirement that SEC determine whether its regulations will "promote efficiency, competition and capital formation" to require marginal cost-benefit analysis); New Mexico Growers Ass'n v. U.S. Fish \& Wildlife Serv., 248 F.3d 1277, 1285 (10th Cir. 2001) (interpreting Endangered Species Act $\S 4(\mathrm{~b})(2)$ 's requirement that FWS consider "the economic impact of specifying" listed species' critical habitat as requiring "a full analysis of all of the economic impacts of a critical habitat designation, regardless of whether those impacts are attributable co-extensively to other causes"); Corrosion Proof Fittings, Inc. v. EPA, 947 F.2d 1201, 1214-17 (5th Cir. 1991) (construing the Toxic Substances Control Act $\S 6(c)(1)(D)$ 's requirement that EPA analyze "the reasonably ascertainable economic consequences" of its rule by citing Aqua Slide, 569 F.2d 831, as requiring EPA to use cost-benefit analysis).

27 See Marjolein B.A. van Asselt \& Ortwin Renn, Risk Governance, 14 J. RISK RES. 431, 436-38 (2011) (calling attention to the uncertainty, complexity and ambiguity of risk grounded in the plurality of hazards, the uncertainties of causation, prediction, and variation, etc.); CHRISTOPHER HOOD ET AL., THE GOVERNMENT OF RISK: UNDERSTANDING Risk REgUlation REgIMES 3-4 (2001).

28 Isolating and monetizing regulation's benefits has long been an identifiable subfield. See, e.g., A. MYriCK FrEEMAN III, THE BENEFITS OF ENVIRONMENTAL IMPROVEMENT: THEORY AND PRACTICE (1979).

29 The general problem of induction aside, risk has invited as much attention from philosophers of science and mind over the last century as it has from economists and economic theory. Risks are inherently forward looking, albeit with informational roots in the past and present. See MichaEl V. Frank, Choosing SAFETy 14-26 (2008). Despite early hopes that so much attention would eventually yield shared probabilistic frameworks for evaluation, risk has 
is to be done some form of harm. ${ }^{30}$ Often, though, the nature and not just the degree of that harm depends on the probabilities at issue. And risk regulation's costs may distribute independently of any of that. The costs of risk regulation have nothing necessarily in common with its benefitsnot its agents, events, causes, or consequences. There is, for example, the wholly discrete and independent sum of government's costs of action in risk regulation. ${ }^{31}$ Stated formally, thus, if expected risk $\boldsymbol{r}$ is the sum of all possible hazards ( $h$ ) up to $n$ hazards in the absence of choice option $\boldsymbol{\varphi}$, where $p$ is each hazard's probability-

$$
(\boldsymbol{r})^{\exp }=\sum_{\exp }\left\{h^{1}(p)+h^{2}(p)+h^{3}(p) \ldots n\right\}
$$

- then $\varphi$ 's costs bear no necessary relationship to the risks faced by those weighing $\phi$ against other options. ${ }^{32}$ We should say that $\varphi$ 's costs are a sum exogenous to $\boldsymbol{r}$ with distinct probabilistic, epistemic, and cognitive challenges. ${ }^{33}$ So the costs and benefits of any given risk regulation may

remained a divisive and lumpy field. "If we were all-knowing and present everywhere all the time, we'd be able to see all possible outcomes of all our possible decisions and actions. Risk arises from our inability to reliably predict the future." Id. at 22.

30 Cf. JoHn OberdieK, Imposing Risk: A Normative Framework (2017) (presenting the argument that to impose risk on others is to deprive them of autonomy to which they are at least presumptively entitled); Claire Finkelstein, Is Risk a Harm?, 151 U. PA. L. REv. 963 (2003) (offering a conditional "yes"). To be put at risk by collective decision making is to be done the harm by a collective-some mechanisms of which can be more problematic than others. See HENRY S. RichARDSON, DEMOCRATIC AutONOMY 234-37 (2002).

31 See Chapter 6, Section 6.2.

32 Stating a sum of $\varphi$ 's costs can highlight the existence of discrete vectors. Thus, cost $=\mathrm{C}_{i}(\boldsymbol{a}, \boldsymbol{z})$, where $\boldsymbol{a}$ is a parameter or vector of parameters describing some option $\varphi, z$ is a vector of parameters summarizing the current economic equilibrium, and $\mathrm{C}_{i}(\boldsymbol{a}, \boldsymbol{z})$ is the associated costs borne by the agent $i$. See William A. Pizer \& Raymond Kopp, Calculating the Costs of Environmental Regulation, in 3 HANDBOOK OF ENVIRONMENTAL ECONOMICS 1307, at 1309-10 (Karl-Göran Mäler \& Jeffrey R. Vincent eds., 2005).

33 The challenges of prediction will distribute independently, and perhaps unevenly, in these distinct calculations. That creates its own methodological choices. See Colin Howson \& Peter Urbach, Scientific Reasoning: The BAYESIAN APPROACH (3d ed. 2006) (arguing that all rational inquiries, especially recognizably "scientific" inquiries, possess ineradicable subjectivities and that the choice of probabilistic methods must be made according to the best all-things-considered assessments, case by case). As Sunstein and others routinely note, having to make such choices will then introduce various cognitive biases. See SunSTEIN, supra note 1 at 33-49. 
(and perhaps should) comprise two theoretically and practically distinct analyses, each with their own forms of uncertainty and variability, types of proof and relevant expertise, and, most especially, their own independent conclusions. ${ }^{34}$

For whatever reason, delegative legislation has long been characteristically vague on how and whether to combine these inquiries. ${ }^{35}$ (The study of the political dynamics therein has itself been practically stalemated for reasons beyond our scope. ${ }^{36}$ ) When Congress deliberates over new legislation, each chamber and the President consider delegating the authority to govern discrete, salient risks against a potentially infinite array of risks and uncertainties. ${ }^{37}$ These are, in American constitutional terms, compound political questions of estimation, prioritization, and

34 The orthodox concession - that without monetization, costs and benefits remain incommensurable-obscures this separability thesis. $C f$. HoOD ET AL., supra note 27 at 70-89 (explaining a general approach to risk regulation grounded in a "market failure hypothesis"); PRESIDENTIAL/CONGRESSIONAL COMMISSION ON RISK ASSESSMENT AND RISK MANAGEMENT, 2 RISK ASSESSMENT AND Risk MANAGEMENT IN REgUlatoRY DECISION-MAKING 19-29 (1997) (treating risk as the product of hazard times exposure). Furthermore, as our national academies have found repeatedly in studying hazards like toxins, segregating elements of the search/investigation is often vital to success. See, e.g., NATIONAL ReSEARCh COUNCIL, SCIENCE AND Judgment IN Risk AssessMENT 4-5 (1994) (listing hazard identification, dose response assessment, exposure assessment, and risk characterization as the divisible elements in understanding the risks of hazardous air pollutants).

35 Prevailing Supreme Court doctrine maintains that delegative legislation ambiguous on the "precise question" at issue in a challenge to agency action normally should be interpreted as authorizing any "reasonable" agency interpretation thereof where the agency's interpretation is embodied in some action having the "force of law." See Chevron, U.S.A., Inc. v. Natural Resources Defense Council, Inc., 467 U.S. 837, 842044 (1984); United States v. Mead Corp., 533 U.S. 218, 227-31 (2001); City of Arlington v. FCC, 133 S. Ct. 1863, 1868-75 (2013).

36 Arrow, Borda, and Condorcet voting paradoxes, like the many theorems they have spawned, implicitly question the democratic legitimacy of legislation and have done so for the bulk of its existence. See Dennis C. Mueller, PubliC CHOICE III 2-6 (2003). The theorems long resisted empirical testing, see GERRY MACKIE, DEMOCRACY DEFENDED 23-71 (2003), but a relative balance of empirical confirmations versus disconfirmations today has left a veritable stalemate in the study of legislative delegation and democratic autonomy. See STEVEN P. Croley, Regulation and Public Interests: The Possibility of Good REGULATORY GOVERNMENT 14-76 (2008).

37 See, e.g., Adrian Vermeule, LaW's Abnegation: From LaW's EMPIRE to the AdMinistrative State (2016). 
institutionalization. ${ }^{38}$ Yet reviewing courts consistently find that, once a statute has delegated authority to some administrator, the ensuing decisions - regardless of their origins in an opaque text forged in political compromise-are fully subject to judicial review for consistency with "the law."39 We may call this the Overton Park consensus for the landmark precedent that announced it. ${ }^{40}$ Upon review such decisions are typically scrutinized for demonstrable arbitrariness, routinely testing the boundaries between administrative and judicial competence. ${ }^{41}$ For what is arbitrary in the context of contemporary risk regulation?

The Securities and Exchange Commission's (SEC) corporate governance rulemakings came to just this intersection some years ago. ${ }^{42}$ Across a line of cases, the Court of Appeals for the District of Columbia Circuit, a court that had long made clear that it would scrutinize the evidence for

38 A "political" question in American terms is one without "judicially discoverable and manageable standards for resolving it." Baker v. Carr, 369 U.S. 186, 217 (1962).

39 In Citizens to Preserve Overton Park v. Volpe, 401 U.S. 402 (1971), the Supreme Court held that even legislation created from inscrutable compromise, delegating to the agency the duty to assess "feasible or prudent alternative[s]," id. at 405, created "law to apply" and thus judicially reviewable agency action consistent with the Administrative Procedure Act (APA), 5 U.S.C. $\$ 551$ et seq. See id. at 416-19. Overton Park's legacy, arguably, has been to substitute judicial for political review along several margins. See Peter L. Strauss, Citizens to Preserve Overton Park v. Volpe-Of Politics and Law, Young Lawyers and the Highway Goliath, in Administrative LAW StORIES 259 (Peter L. Strauss ed., 2006).

40 The US Supreme Court's most noted accounts of the arbitrariness review standard(s) grew more or less directly from Overton Park. See Merrick B. Garland, Deregulation and Judicial Review, 98 HARV. L. REV. 505, 541 (1985).

$41 C f$. VERMEULE, supra note 37 (arguing that law and legal theory from the early twentieth century to the present and for the foreseeable future must grapple with the interface of judicial and administrative authority).

42 See John C. Coates IV, Cost-Benefit Analysis of Financial Regulation: Case Studies and Implications, 124 YALE L.J. 882, 890-902 (2015) (discussing Chamber of Commerce v. SEC, 412 F.3d 133 (D.C. Cir. 2005); Business Roundtable v. SEC, 647 F.3d 1144 (D.C. Cir. 2011); Nat'l Ass'n of Mfrs. v. SEC, 748 F.3d 359 (D.C. Cir. 2014)). 
SEC's economic findings, ${ }^{43}$ confronted SEC's economic analysis, challenged for having drawn "arbitrary" inferences from inconclusive evidence. ${ }^{44}$ The claim was that SEC failed to quantify costs-costs the agency had said were not quantifiable. ${ }^{45}$ In Chamber of Commerce $v$. $S E C, 46$ the Court "subtly elevated the statutory mandate for the SEC to 'consider' efficiency, competition and capital formation to [an] independent obligation to determine (as best it can) the economic consequences of proposed rules." 47 Subtle or not, though, judicial interventions like this can have profound consequences. ${ }^{48}$

Consider the use of disclosures to discourage the sourcing of materials from "conflict" locations like the Democratic Republic of Congo. ${ }^{49}$ The civil war there has been particularly brutal and resistant to resolution. Congress had directed SEC to require any person manufacturing a product where "conflict minerals are necessary to the functionality or production of [that] product" to disclose that fact in standard SEC filings and SEC obliged, promulgating a series of disclosure duties. ${ }^{50}$ The disclosures SEC elected to require would be burdensome to assemble, with estimated compliance costs of \$3-4 billion upfront and roughly \$200-600 million annually thereafter. ${ }^{51}$ When it came time to estimate the benefits of the disclosure rule-disclosures being the tool chosen to

43 See Bruce Kraus \& Connor Raso, Rational Boundaries for SEC CostBenefit Analysis, 30 YALE J. REG. 289, 298-300 (2013) (discussing Timpanaro v. SEC, 2 F.3d 453 (D.C. Cir. 1993)).

44 See, e.g., Business Roundtable, 647 F.3d at 1148-56.

45 See Coates, supra note 42 at 891-96, 912-26. One proposal, given how little confidence SEC had in direct estimations of costs of financial regulation, was to fashion a model, albeit one that would by necessity be extraordinarily complex. See id. at 943-47.

46412 F.3d 133 (D.C. Cir. 2005).

47 Kraus \& Raso, supra note 43 at 305 (emphasis in original) (discussing Chamber of Commerce, 412 F.3d at 143).

$48 C f$. Kraus \& Raso, supra note 43 at 292 (noting that challenges were " 100 percent successful to date" where they have attacked SEC rulemakings on grounds of inadequate cost-benefit analysis).

49 Congress included a mandate in the Dodd-Frank Wall Street Reform and Consumer Protection Act to SEC that SEC require disclosures from certain types of firms with business in covered countries. See Securities and Exchange Commission, Final Rule-Conflict Minerals, 77 Fed. Reg. 56274, 56277-78 (2012).

50 See Pub. L. No. 111-203, 124 Stat. 1376, at $\S 1502$ (2010), codified in relevant part at 15 U.S.C. $\S \S 78 \mathrm{~m}(\mathrm{p}), 78 \mathrm{~m}$ note.

51 See Securities and Exchange Commission, Final Rule-Conflict Minerals, 77 Fed. Reg. 56274, 56334 (2012). 
alert markets to the uses of "conflict minerals" so that market actors could avoid them-SEC was deeply uncertain. Indeed, it "was "unable to readily quantify' the 'compelling social benefits' the rule was supposed to achieve: reducing violence and promoting peace and stability in the Congo." ${ }^{2}$ Lacking data on how effective the disclosures could or would be in real markets, ${ }^{53}$ it opted instead to rely on "Congress's judgment that supply-chain transparency would promote peace and stability by reducing the flow of money to armed groups." 54 Was that arbitrary? ${ }^{55}$ Certainly SEC might have surveyed Americans to discover what they were willing to pay to peaceably resolve the war in Congo. ${ }^{56}$ It chose not to do so. Was it arbitrary to deny a de minimis exemption from the disclosure requirements? Surely SEC might have decided that Congress did not intend to impose heavy compliance costs on someone playing virtually no role in the Congo's multifaceted, long-enveloping tragedy. It chose not to do so.

On both counts the reviewing court found that SEC had not been arbitrary—-that it had good and sufficient reasons for its rule. ${ }^{57}$ But what

52 National Ass'n Mfrs. v. SEC, 748 F.3d 359, 364 (D.C. Cir. 2014) (quoting Conflict Minerals Rule, 77 Fed. Reg. at 56350)).

53 See Nat'l Ass'n Mfrs., 748 F.3d at 364.

54 See id.

55 A general authority to review agency action not otherwise withdrawn specifically by statute is available from APA $\S 10$. The broadest grounds for setting aside agency action in that statute is that the action is adjudged "arbitrary, capricious, an abuse of discretion or otherwise not in accordance with law." Id. at $\S 706(2)(\mathrm{A})$. In this case, the five-member Commission voted three to two to make the rule. Nat'l Ass'n Mfrs., 748 F.2d at 363.

56 Americans' expressed willingness to pay to avoid the harms of Congo's civil war might be relevant. See Eric A. Posner \& Cass R. Sunstein, Moral Commitments in Cost-Benefit Analysis, available at https://papers.ssrn.com/sol3/ papers.cfm?abstract_id=2930450 at 17-19. Then again, the collection and use of such data may well have been to dismiss Congress's evaluation of avoiding conflict minerals-a choice which itself could be judged "arbitrary" or "not in accordance with law." Cf. State Farm, 463 U.S. at 52 (holding that, where a rule's benefits accrue as to the risk the statute targets, rescinding that rule requires at least an explanation in keeping with the statute's purposes and text).

57 See Nat'l Ass'n Mfrs., 748 F.3d at 364. Contemporary moral theory typically takes as given some substantive theory of rational action, whether as a matter of individual or collective agency. See DAVID SchmidTZ, RATIONAL Choice And Moral Agency (1995). US federal courts rarely resort to such theory, at least explicitly-although struggles with the rules of recognition applicable to agency reasons are quite common. See Jacob Gersen \& Adrian Vermeule, Thin Rationality Review, 114 Мich. L. REV. 1355 (2016). 
had SEC's decision procedure been ${ }^{58}$ How did it justify its ignorance of the benefits of its rule? Would it have been prohibitively costly to have collected data showing its rules' costs were justified by their benefits? ${ }^{59}$ Would Americans' expressed "willingness to pay"60 have been that data? To be sure, SEC had good reason to pause on the strategic ramifications of taking such an approach. ${ }^{61}$ Data of the kind rarely come with their own assurances of accuracy, whatever the costs of their collection. ${ }^{62}$

SEC might have answered that the disclosure requirements were justified because they were the right or just thing to do. ${ }^{63}$ Lurking, often, is a right/wrong boundary-foreign as that dichotomy can seem to economics - in talk of costs and "willingness to pay."64 All-thingsconsidered justifications that turn to some extent on fairness or justice are pervasive in life. Utilitarianism's most powerful synthesis struggled

58 SEC need not have resorted to "economic" reasoning to have followed some decision procedure. See, e.g., John Rawls, Outline of a Decision Procedure for Ethics, 60(2) PHIL. REV. 177 (1951). This is the only way that competent agents can gain assurances that they have tallied the reasons for and against relevant options, though. Id. at 185-96.

59 In many contexts, the government's own "decision costs" are a relevant decisional factor. See Gersen \& Vermeule, supra note 57 at 1390-96.

60 So-called "willingness-to-pay" data, from surveys or other means, put a price to benefits that lack direct pricing information. See SUNSTEIN, supra note 1 at 180 .

61 Cognitive psychologists have revealed important shortcomings in survey research. See DANiEl Kahneman, Thinking, FAST AND Slow (2011); $c f$. John C. Harsanyi, Morality and the Theory of Rational Behavior, in UTILITARIANISM AND BEYOND 39 (Amartya Sen \& Bernard Williams eds., 1982) (arguing that rational prudence must include at least a minimal account of the "social setting" of the decision wherein others' preferences are uncertain). "The concept of rational behaviour arises from the empirical fact that human behaviour is to a large extent goal-directed behaviour.' Id. at 42. Assuming SEC's goals included minimizing its own costs, conducting willingness-to-pay survey research in support of a rule might not have been "means-ends rational" - to say nothing of that research's problems with accuracy. See Wendy E. Wagner, Administrative Law, Filter Failure, and Information Capture, 59 DuKE L.J. 1321, 1351-65 (2010) (describing causes and consequences of "information excess" in regulation).

62 See, e.g., Matthew D. Adler \& Eric A. Posner, New Foundations of COST-BENEFIT ANALYSIS 166-73 (2006) (noting several problems with "willingness-to-pay" data, especially the potential for strategic misrepresentations).

63 See, e.g., CASS R. Sunstein, Free Markets AND Social Justice 96 (1997) ("[E]ven a system that generally respects freedom of contract may block exchanges on several grounds.").

64 See, e.g., Harsanyi, supra note 61 at $40-41$. 
mightily with the existence of some ostensibly "ultimate" good exceeding all other goods. ${ }^{65}$ Judging goodness and rightness separately puts considerable stress on their distinction. ${ }^{66}$ Yet the good and the right may be different (in philosophy if not economics) even if they are practically impossible to disentangle. ${ }^{67}$

So even conceding that goodness fully decides rightness, the metaphor of weighing the good and bad of an option remains deceptively simplistic. ${ }^{68}$ Like any metaphor, it suppresses differences to highlight similarities. We like to weigh factors, each with its own valence in our evaluative frameworks. ${ }^{69}$ But just as any set of things' weight can be their thinnest commonality, considerations for and against an option are rarely the only reasons pertaining to that option. ${ }^{70}$ Principals and agents, for

65 See Henry Sidgwick, The Methods of Ethics 391-407 (7th ed. 1907) (Hackett 1981); cf. J.B. SCHNEEWIND, SIDGWICK's ETHICS AND VictORIAN MORAL PHILOSOPHY 310-28 (1977) (explaining Sidgwick's struggle).

$66 C f$. ADLER \& POSNER, supra note 62 at 52-61 (arguing that welfare as a metric of goodness need not be morally exclusive and fielding the common objections to the use of welfare as a moral criterion); SCHMIDTZ, supra note 57 at 98-106.

67 Properly Kantian or Rawlsian principles of rightness-even merely "intuitionistic" agreements to the same effect-could have justified the DoddFrank Act's posture toward DRC's civil war. See, e.g., JOHN RAWLS, JUSTICE AS FAIRNESS: A RESTATEMENT 5-9, 13-14 (2001) (discussing the ideals of a society as a "fair system of cooperation," the "well-ordered society" and how Kant viewed justice as a global obligation); DEREK PARFIT, 1 ON WHAT MATTERS 377-80 (2011) (defending a "Kantian" version of "rule consequentialism").

68 On weighing and how it contrasts with "lexical priority" views, see Michael Huemer, Lexical Priority and the Problem of Risk, 91 PAC. PHIL. Q. 332 (2010); but cf. BROOME, supra note 24 at 7 ("Not all teleological judgement need be much like weighing .... It is consistent with teleology to think that some considerations dominate others lexically."). Still, the weighing metaphor-which some find problematic on metaethical grounds, see, e.g., Douglas A. KYSAR, REGULATING FROM NOWHERE 38-45 (2010)—need not account for all the ways in which costs matter.

69 See, e.g., Shelly Kagan, Normative Ethics 17-22 (1998) (observing that normative, "commonsense" ethics can be divided into "factors" such as the good, doing harm, and honesty, and "foundations" in either teleology or deontology).

70 Whether we take the class of all reasons, i.e., as favorers or disfavorers, see T.M. SCANLON, WHAT WE OWE TO EACH OTHER 17 (1998), or rather split the range of reasons into distinct kinds having different bases of normativity, see, e.g., John Skorupski, The Domain of REASOns (2011), every reason can be judged as such both for its validity and its sufficiency. Unidimensional weighing collapses that distinction. 
example, often have much thicker relationships than any particular choice can reflect. Thus, taking the private costs of complying with the SEC's Congo standards as (relatively) high and the uncertain benefits as being (mostly) overseas, the sum of SEC's reasons may have seemed to be against making that rule. ${ }^{71}$ Congress, however, had decided for its own reasons to direct SEC to require disclosures, whatever good SEC thought might come of it. $^{72}$ How was SEC to serve Congress? Its being Congress's agent entailed that question. Of course, a de minimis exemption was not necessarily ruled out by the legislation. ${ }^{73}$ For all could be told, Congress simply ignored that option. But it seems that SEC decided that the lack of cause-to-effect ties linking US capital investment to suffering in central Africa was insufficient reason for a de minimis exemption. ${ }^{74}$ As SEC seemed to suggest, costs may do better as some kind of proxy for justice or fairness in this context than as a metric for utility or welfare. ${ }^{75}$ Particularly in contexts where a fair system of

71 How to count (or weigh) the good of foreign nationals against that of American citizens and/or how to consider the "diminishing marginal utility" of goods like money income relative to goods like security or safety entail severe operational and epistemological troubles, severely complicating most economic methods. See, e.g., Kenneth J. Arrow, Some Ordinalist-Utilitarian Notes on Rawls' Theory of Justice, 70(9) J. PHIL. 245 (1973).

72 Teleological approaches depart from other approaches, we might say, in their evaluation of acts, choices, etc., by the goodness or the badness thereof. Goodness determines rightness for teleological approaches. See BROOME, supra note 24 at $6-13$. And "[t]he standard sort of teleology is maximizing." Id. at 6. But this entailment is both strength and weakness, especially where the goods being weighed are not (or may not be) additive. See Shelly Kagan, The Additive Fallacy, 99(1) ETHICS 5 (1988).

73 But see 748 F.3d at 366 ("Having established that conflict minerals are frequently used in minute amounts, the Commission could reasonably decide that a per-issuer exception could 'thwart' the statute's goals by leaving unmonitored small quantities of minerals aggregated over many issuers.").

74 Assigning weights to moral reasons may be a uniquely problematic exercise. See Michael Philips, Weighing Moral Reasons, 96 Mind 367 (1987). Furthermore, any theory of "doing harm" will rest on causal foundations which become question-begging beyond the simplest cases of act/consequence. See, e.g., Carolyn R. Morillo, Doing, Refraining, and the Strenuousness of Morality, 14(1) AMER. PHIL. Q. 29 (1977). And as Section 2.1 demonstrates, consequentialist reasons are pervasive in contemporary risk regulation.

75 Utility as a measure of "good" has long wrestled with peoples' preferences for fairness and justice. See John Broome, Utility, 7 Econ. \& PHIL. 1 (1991). American courts rather pragmatically ignore the basic concept of cost's conflation of the two. See, e.g., U.S. EPA v. EME Homer City Gen., 134 S. Ct. 1584 (2014) (upholding EPA's use of abatement costs to assign proportional 
cooperation is at stake, indeed, utility and welfarism can obscure the relevance of costs as choice factors. ${ }^{76}$ If I need others' help to accomplish my goals, for example, I must deal with them as they are-not as I believe they should rationally be. ${ }^{77}$ If they think my behavior unfair, my calculation of costs or benefits will be beside the point. In the SEC's case, while the reviewing court found "exhaustively analyzed" costs, "immeasurable" benefits, and laudable goals, the path to final reasonableness did not begin or end with a cost-benefit criterion. ${ }^{78}$

So what sort of consideration must cost be when it arises in delegated risk regulation? In a secular world, costs are characteristically confined to those costs befalling persons, whether natural or legal. But which persons ${ }^{79}$ Championing or mandating cost-benefit analysis in risk regulation presupposes that cost is a coherent (economic) concept. ${ }^{80}$ But is it? If projected costs can be avoided and not experienced, were they ever really "costs"? Economics has more trouble with that question than you might think. A projected cost is an odd thing. Costs are innately sensitive to temporal position, i.e., past, present, future. For example, an earlier era of "reasonable" price regulation came to a close without ever really

responsibility to upwind states for downwind nonattainment of uniform national standards).

76 A powerful exploration of the rifts exposed in utilitarianism by the "universalization" of acts and consequences is DAVID LYONS, FORMS AND LIMITS OF UTILITARIANISM (1965).

77 See id. at 177-97. If the "others" whose cooperation is needed comprise discrete social groups or firms, formal rationality can become an even bigger obstacle. See, e.g., The Firm AS a Collaborative Community: ReCONSTRUCTING TRUst IN THE KNOWLedge ECONOMY (Charles Heckscher \& Paul S. Adler eds., 2006).

78 Nat'l Ass'n Mfrs., 748 F.3d at 369-70.

79 A once prominent critique of fully secularized ethics cast it as no more than "emotivism" and argued that, notwithstanding the dominance of secular ethics since the Enlightenment, it is essentially incoherent. See ALASDAIR MACINTYRE, AFTER VIRTUE (2d ed. 1984). A more lasting critique of the project of "commonsense morality" —including utilitarian-welfarist ethics—is Derek Parfit's Reasons and Persons (1986). Skepticism of welfarist ethics since Parfit has often taken aim at how the relevant people to be protected are selected and identified. See, e.g., KYSAR, supra note 68; John BroOME, WEIGHING Lives (2004).

80 In their "textbook" of the subject, Mishan and Quah offer no introduction, preface, or glossary entry and, in a part devoted to "basic concepts," presume agreement on the tenets of welfare economics in explaining specific types of "cost." See E.J. Mishan \& Euston Quah, Cost-Benefit Analysis (5th ed. 2007). 
resolving whether the "costs" to be recouped through prices should be calculated on an average or on a marginal basis. ${ }^{81}$ Marginal cost accounting ignores the past-because nothing can be done about it! 82 From that experience to the present, regulation's costs have proven a protean field of concepts which has both expanded and contracted its place in risk regulation. ${ }^{83}$ Indeed, as this monograph explores, economic cost as a consideration in regulation hides within it a series of seemingly intractable choices about what to measure, when, and how.

Finally, cost-benefit analysis - an increasingly professionalized economic decision procedure-is rarely legislated in terms. More often, legislation directs regulators simply to consider costs. ${ }^{84}$ Thus, reviewing courts are most apt to hold that, given such legislative ambiguity, costs are to be estimated and evaluated by those who are delegated the authority. ${ }^{85}$ And although our "commonsense" talk of right and wrong often defaults to a form of "factor balancing" in which foundational issues are bracketed and factors favoring or disfavoring a choice are "weighed" against other factors, ${ }^{86}$ this says nothing necessarily about

81 See Alfred E. Kahn, The Economics of Regulation: Principles And INSTITUTIONS 63-75 (2d ed. 1988).

82 Confining cost accounting to only those costs that can be avoided is arguably the business firm's strategic imperative. See Robin Cooper \& Robert S. Kaplan, Measure Costs Right: Make the Right Decisions, HARV. Bus. Rev. 96 (Sept.-Oct. 1988).

83 In their classic account Revesz and Livermore argue that, although cost-benefit analysis was, as then practiced, "biased against regulation," "those biases are not inherent to the methodology." RICHARD L. REVESZ \& MiCHAEL A. LIVERMORE, RETAKING RATIONALITY 10 (2008). Indeed, in their view for many kinds of regulation, "the use of cost-benefit analysis is a requirement of basic rationality." Id. at 12. In an earlier classic McGarity juxtaposed what he called "techno-bureaucratic rationality" with "comprehensive analytical rationality," with the latter tending toward the economist's professional ethos and the former toward the engineer's. See ThOMAs O. MCGARITY, REINVENTING Rationality: The Role of Regulatory Analysis in the Federal Bureaucracy 4-16 (1991). Chapter 3 explores that division in detail.

84 Each of the case studies in Chapters 4, 5 and 6 explore specific legislative mandates in context.

85 See, e.g., New York v. Reilly, 969 F.2d 1147, 1150 (D.C. Cir. 1992) (construing provision requiring that costs be taken into consideration and concluding that "[b]ecause Congress did not assign the specific weight [EPA] should accord each of these factors," it is up to the agency's sound discretion).

86 See, e.g., Shelly Kagan, Normative Ethics 17-22 (1998) (dividing the understanding of normative, "commonsense" ethics into "factors" and "foundations"). 
what any particular legislative delegation must necessarily mean. Society may care about risk regulation's costs for different reasons.

\subsection{THREE REASONS TO ESTIMATE AND TO EVALUATE COSTS}

Cost's role in the pursuit of public welfare has been, in practice, the core concern. ${ }^{87}$ Cost in this tradition is a quantity to be minimized if regulation's (net) benefits are to be maximized. ${ }^{88}$ This kind of utilitarian or teleological criterion is endemic to orthodox economics ${ }^{89}$ and, by extension, to contemporary cost-benefit analysis. ${ }^{90}$ Its challenges stem from specifying the public's "goods," weighing disparate goodsespecially goods as valued by different people at different times or places-and assessing the realized "opportunity costs" of acquiring one good instead of others. ${ }^{91}$

But cost also might indicate a kind of imprecision or uncertainty in an agent's focus or purpose, implicating different concerns. Even assuming a more or less utilitarian theory of legislation, the principal-agent dynamics in delegations involving risk can reveal critical insights into the public's good. ${ }^{92}$ Cost in this light can be a surrogate for means-ends

87 See ADLER \& POSNER, supra note 62 at 9-24.

88 See, e.g., REVESZ \& LIVERMORE, supra note 83 at 12-13; SUNSTEIN, supra note 1 at 19-22; MCGARITY, supra note 83 at 17-25; THEODORE M. PORTER, Trust in Numbers: The Pursuit of ObJectivity in SCIENCE AND Public Life 148-89 (1995).

89 See, e.g., Paul A. Samuelson \& William D. Nordhaus, Economics (19th ed. 2009). "Social" cost in this tradition is whatever lost opportunities or charges taken result from public policy choices. See, e.g., CHARLES D. KOLSTAD, ENVIRONMENTAL ECONOMICS 22 (2000) (asserting that total US expenditures on pollution abatement "are approximately $2 \%$ of gross domestic product (GDP)"). Properly "social" costs can be very difficult to identify in practice, though, as Chapters 2 and 3 explore in detail.

90 See, e.g., REVESZ \& LiVERMORE, supra note 83 at 12-13; Mishan \& QUAH, supra note 80 at 10; ADLER \& POSNER, supra note 62 at 1-8.

91 See Elizabeth Anderson, Value in Ethics And Economics (1993); Broome, supra note 24; J.A. Mirrlees, The Economic Uses of Utilitarianism, in UTILITARIANISM AND BEYOND 63 (Amartya Sen \& Bernard Williams eds., 1982); William J. Baumol \& Wallace E. OATES, The Theory of EnVironmental POLICY 14-32 (2d ed. 1988).

92 Professor Boyd demonstrated this long-run process at work-perhaps unintentionally - in tracing the rise of risk-focused regulation in the US from fits and starts to an "administrative law of unreasonable risk." See William Boyd, 
irrationality: In a world of uncertain and dynamic utilities and risks, we often use the information at hand as a rough guide to discerning our own true ends or purposes. ${ }^{93}$ The matter can be immensely more complex when ends are to be given by an internally plural principal (not the agent) in punctuated expressions like legislation. Cost is still, in this regard, a tool for serving ends or purposes. But its real use is to keep the interactivity of means and ends tractable, evident, and current.

Finally, regulatory costs might be an altogether different sort of consideration: a decisional input which, though not itself directly relevant or representative, maintains a kind of back pressure in the decision domain. In this mediative role, costs can serve to buffer the inevitable frictions between efficiency and fairness. For example, the US Congress has often directed regulators to set "performance standards" 94 that require the best performance "feasible" or which is achievable by the affected (market) actors. In that context, cost-as-burden mixes considerations of fairness and efficiency, as Chapter 3 explains and two later case studies explore in detail.

Without knowing which of these roles costs are to play, though, decision makers will struggle with precisely how they are to be tabulated and evaluated.95 Indeed, even where cost is but an ingredient of costbenefit welfarism, its varied uses have often confounded decision makers.

Genealogies of Risk: Searching for Safety, 1930s-1970s, 39 ECOL. L.Q. 895 (2012). Another example worth considering is the European Union's pivot toward climate change and the impact that that had on the EU's overall risk governance principles. See Veerle Heyvaert, Governing Climate Change: Towards a New Paradigm for Risk Regulation, 74 MoD. L. REV. 817 (2011). Professor Heyvaert tracks the role of "fictional certainty" in contemporary EU risk regulation, id. at 821 , and how climate change's twin problems of mitigation and adaptation undermined that, forcing an institutionally fragmented system to come back together in governing the different elements of climate risk as a disordered whole.

93 See, e.g., SCHMIDTZ, supra note 57 at 58-66 (describing the kinds of ends that are adopted for the sake of acquiring settled ends). "Instrumental or static rationality involves seeking effective means to given ends. The essence of reflective rationality is that, although it involves means-end reasoning, it goes beyond instrumental rationality because it does not take ends as given.' Id. at 70.

94 A "performance standard" specifies an outcome while leaving the measures to achieve that outcome open for the regulated party/ies to select. See Cary Coglianese, The Limits of Performance-Based Regulation, 50 U. MicH. J.L. REF. 525, 526-31 (2017).

95 Given the difficulties of weighing moral factors against one another, see, e.g., Michael Philips, Weighing Moral Reasons, 96 Mind 367 (1987) (showing that moral weights differ by circumstances), if cost can be either a fairness or 
The "feasibility analysis" OSHA named in American Textile Mfrs..$^{96}$ as an alternative to cost-benefit analysis is still debated for whether and how it actually differs from the simple comparison of costs to benefits. ${ }^{97}$ OSHA has long maintained that its feasibility analysis is not cost-benefit analysis and reviewing courts have uniformly agreed. ${ }^{98}$ Yet OSHA strives to monetize both costs and benefits all the same. ${ }^{99}$ EPA monetizes costs and benefits in most of its "technology-based" standards, often refining the standard to maximize the difference. ${ }^{100}$ More recent "breakeven" variants of cost-benefit analysis ${ }^{101}$ presume that cost estimates can and should occupy some privileged position in regulatory decisions-that, in essence, only benefits' surpassing costs can warrant regulatory action. ${ }^{102}$ Yet we have good reasons to doubt such monistic thinking in general ${ }^{103}$ and such a strict cost/benefit criterion in particular. ${ }^{104}$ Only where

efficiency consideration, how or even whether it aligns with other reasons for a proposed action may be deeply uncertain. Section 2.1.1 elaborates.

96 See supra notes 9-18 and accompanying text.

97 See, e.g., Driesen, supra note 23; Amy Sinden et al., Cost-Benefit Analysis: New Foundations on Shifting Sand, 3 REG. \& GovernANCE 48 (2009); Matthew Adler \& Eric A. Posner, New Foundations of Cost-Benefit Analysis: A Reply to Professors Sinden, Kysar, and Driesen, 3 Reg. \& Governance 72 (2009); Jonathan S. Masur \& Eric A. Posner, Against Feasibility Analysis, 77 U. CHI. L. REV. 657 (2010); David M. Driesen, Two Cheers for Feasible Regulation: A Modest Response to Masur and Posner, 35 HARV. ENVTL. L. REV. 313 (2011).

98 See, e.g., Public Citizen Health Research Group v. U.S. Dept. of Labor, 557 F.3d 165, 177 (3d Cir. 2009).

99 See Note-OSHA's Feasibility Policy: The Implications of the "Infeasibility” of Respirators, 129 HARV. L. REV. 2235, 2237-42 (2016).

100 See Chapters 4 and 5.

101 See, e.g., Daniel Farber, Breaking Bad? The Uneasy Case for Regulatory Breakeven Analysis, 102 CAL. L. REV. 1469 (2014).

102 "[B]reakeven analysis is a kind of conditional cost-benefit analysis that asks, 'How high would the benefits have to be for the regulation to be justified?'." Farber, id. at 1470.

103 See ANDERSON, supra note 91 (articulating and defending a pluralistic theory of value in ethics and economics).

104 Whether lost opportunities or charges incurred are a "cost" or a "benefit" will often come down to point of view and, supposing they involve individuals of varied points of view, may raise the prospect of reciprocal yet asymmetric benefits/costs. See, e.g., Cass R. Sunstein, Incommensurability and Kinds of Valuation: Some Applications in Law, in INCOMMENSURABILITY, INCOMPARABILITY, AND PRACTICAL REASON 234 (Ruth Chang ed., 1997) (arguing that different agents often value the same things in incommensurable ways, preventing comparisons of their gains and losses). 
benefits are as easy to estimate or as determinate as costs can such methods even purport to be analytical, i.e., substantively impartial, tools. ${ }^{105}$

In sum, costs-or, more precisely, our collective sense of cost as a decisional factor in risk regulation-has done without foundations. Cost considerations have been a collection of notions bearing family resemblances but lacking any fixed or immutable foundations. This may explain their longevity and vitality, but it should alert us to their penchant to morph subtly, even undetectably, into very different influences. Section 1.3 sketches the principal role of judicial review in that experience.

\subsection{AN INSTITUTIONAL DIMENSION: JUDICIAL REVIEW OF COST AS A CONSIDERATION}

Especially in an American context, the weighing of costs in regulation cannot be backed out of the totality of experience for study without first understanding judicial review's place as such. By some accounts judicial review or the prospect thereof saturates the average regulatory decision in America, coloring its timing, procedural form, and content. ${ }^{106}$ And, to be sure, the review of factored determinations and factor-constrained policymaking more generally is the subject of a vast professional literature. But this literature does not as a whole show any set of linear or causal relationships. Indeed if anything it underscores the turbulence and unpredictability in judicial review-how courts and agencies interpret statutes differently, how they each handle proof problems, and the wide variety of impacts these forces exert on administration. ${ }^{107}$ In the relatively rare instances where court/agency interactions become serious

105 See Finkel, supra note 20 at 106-11; David M. Driesen, Cost-Benefit Analysis and the Precautionary Principle: Can They be Reconciled?, $2013 \mathrm{MICH}$. ST. L. REV. 771, 807-11.

106 See, e.g., Elizabeth Magill \& Adrian Vermeule, Allocating Power Within Agencies, 120 YALE L.J. 1032 (2011); Louis J. Virelli III, Deconstructing Arbitrary and Capricious Review, 92 N. CAR. L. REV. 721 (2014).

107 Gersen and Vermeule's empirical study of arbitrariness reviews in the US Supreme Court found that the vast majority of cases are decided in the agency's favor and that, as a result, agencies are only required to make decisions on the basis of reasons - not on the basis of objectively good reasons. See Gersen \& Vermeule, supra note 57 at 1358. But that contrasts with a much less lopsided advantage for the agency in the courts of appeal which Miles and Sunstein found in 2008. See Thomas Miles \& Cass R. Sunstein, The Real World of Arbitrariness Review, 75 U. CHI. L. REV. 761 (2008). They also found that "[w]hen agency 
inter-branch conflicts, ${ }^{108}$ it is often judicial opinions that "assur[e] compliance below while avoiding accountability above." 109 That is, discerning the real grounds of such a decision can be challenging to say the least. ${ }^{110}$ It is one thing to note that all agency choices, when challenged in a timely fashion by affected parties with standing to bring a lawsuit, must be grounded in reasons - no matter the precise standard of review. ${ }^{111}$ It is something else again to explain the requisite grounds, force, or normativity of those reasons within and across specific agency contexts. ${ }^{112}$ And yet agency "reasonableness" is the limit in estimations and evaluations of costs which we will encounter over and over in this

decisions are liberal, Democratic appointees are significantly more likely to vote to uphold them than when they are conservative. By contrast, Republican appointees are significantly more likely to uphold conservative agency decisions." Id. at 813. And, of course, arbitrariness review is just one among several different forms of review.

108 As Professor Vermeule has argued repeatedly and at length, courts and agencies rarely come into conflict - relative to their baseline activities-and rarer still is the court order that constrains an agency more than minimally. See Vermeule, supra note 37; Adrian Vermeule, The System of the ConstituTION (2011); ADRIAN VERMEULE, JUdGING UNDER UNCERTAINTY: AN INSTITUTIONAL THEORY OF LEGAL INTERPRETATION 118-48 (2006).

109 Antonin Scalia, Vermont Yankee: The APA, the D.C. Circuit, and the Supreme Court, 1978 SUP. CT. REV. 345, 372. Then-Professor Scalia was referring to a lower court's efforts to guide agencies without being corrected by a higher court.

110 See id. at $372-75$. "It is surely ironic that our judicial system has managed to develop a system of review for definitive administrative statements of intent, but not for functionally similar pronouncements by the courts themselves." Id. at 374.

111 See, e.g., David Zaring, Reasonable Agencies, 96 VA. L. REV. 135 (2010) (arguing that the Court's many different standard of review doctrines have converged to a kind of "reasonableness" review).

112 Cf. Peter L. Strauss, "Deference" is too Confusing-Let's Call Them "Chevron Space" and "Skidmore Weight," 112 ColuM. L. REV. 1143, 1145 (2012) (arguing that deference, like discretion, is a highly variable, if not empty, concept and that what courts are doing in hearing agency statutory interpretations breaks out into two very different kinds of judicial oversight). "Th[e] 'reasoned decision-making' requirement pervades administrative law. The simplicity of the phrase itself, however, misleadingly masks the nuances of its application. It is used to describe judicial review that ranges in intensity from searching hard look to lenient super deference." Emily Hammond Meazell, Super Deference, the Science Obsession, and Judicial Review as Translation of Agency Science, 109 MicH. L. REV. 733, 741 (2011) (internal citations omitted). 
study. Sketching some better contours of this "reasonableness" constraint, thus, is part of this study's burden.

In truth, the US Supreme Court has had an unfortunate tendency to conflate distinct questions when describing or applying its various "standards" of review. Costs in regulation are at least an issue of (1) policymaking judgment, (2) statutory interpretation, and (3) factual proof gathered as such. They may raise other issues, but regulatory costs entail at least these three. Organized by statute to review distinct issues of discretion, law, and fact as they arise in "formal" or "informal" agency adjudications or rulemakings, ${ }^{113}$ US federal courts are supposed to resist the temptation to fashion new agency obligations, whether of a procedural or substantive character. ${ }^{114}$ Record requirements for formal proceedings, for example, should not be imposed upon informal proceedings and review standards appropriate to issues of fact are not to be applied to exercises of discretion. ${ }^{115}$ Still, fuzzy boundaries remain the norm. ${ }^{116}$

113 A "formal" adjudication or rulemaking is conducted "on the record" such that all relevant testimony, exhibits, and other information on which the agency relies is gathered into and recorded in a complete catalogue. "Informal" proceedings have a less structured record and can include "off the record" sources, albeit at the peril of undermining whatever factual support the rule may need upon challenge. See William F. Pedersen, Formal Records and Informal Rulemaking, 85 YALE L.J. 38 (1975); Sierra Club v. Costle, 657 F.2d 298, 400-410 (D.C. Cir. 1981).

114 See Perez v. Mortgage Bankers' Ass'n, 135 S. Ct. 1199 (2015); Allentown Mack Sales \& Serv., Inc. v. NLRB, 522 U.S. 359, 366-67 (1998); Vermont Yankee Nuclear Power Corp. v. Natural Resources Defense Council, Inc., 435 U.S. 519, 546-49 (1978); United States v. Allegheny-Ludlum Steel, 406 U.S. 742, 756-57 (1972); Citizens to Preserve Overton Park v. Volpe, 401 U.S. 402 (1971); SEC v. Chenery, 332 U.S. 194, 202-07 (1947).

115 See generally A Guide to Judicial AND Political Review of Federal Agencies (John F. Duffy \& Michael Herz eds., 2005). The Supreme Court's unfortunate tendency mentioned may stem from its origins in and habits of employing common law methods. See John F. Duffy, Administrative Common Law in Judicial Review, 77 TEX. L. REV. 113 (1999). Whatever the causes, the Court has superintended a long, consistent march toward the "administrative state" so fitfully demonized in American politics today. See JERrY L. MASHAw, CREATING THE Administrative Constitution (2012).

116 "It is not infrequent that the available data do not settle a regulatory issue, and the agency must then exercise its judgment in moving from the facts and probabilities on the record to a policy conclusion. Recognizing that policymaking in a complex society must account for uncertainty, however, does not imply that it is sufficient for an agency merely to recite 'substantial uncertainty' as a justification for its actions." Motor Vehicle Mfrs. Ass'n v. State Farm Mut. Ins. Co., 463 U.S. 29, 52 (1983). 
For decades the consensus has been that review for administrative "arbitrariness" extends at least (and perhaps at most) to whether the agency's decision was based on the relevant factors, to whether a "clear error of judgment" occurred, and to whether the "reasoned basis" for the action could fairly be discerned from the administrative record required by law. ${ }^{117}$ For almost as long, the Supreme Court has maintained that an agency delegated authority by statute is entitled to real judicial deference in interpreting that statute. ${ }^{118}$ But because all of that is predicated upon, and mostly constituted by legislation, the normal vagueness of ordinary language and the untidy decision-making processes of Congress are all that separate an agency's jurisdiction to regulate from what is beyond its reach. ${ }^{119}$ In other words, law constraining when and how costs must or must not be weighed by an agency can often only be differentiated from the discretion vested in that same agency by a knife's edge. ${ }^{120}$

When EPA's authority to set national ambient air quality standards (NAAQS) without considering the costs thereof was challenged, the Supreme Court was inundated with "hundreds of pages of briefing ... submitted on the issue," 121 much to the effect that if EPA could take that initiative itself, the Clean Air Act (CAA) should be held unconstitutional. ${ }^{122}$ In rejecting the challenge, the Court unanimously held that CAA $\S 109$ (b)'s failure even to mention costs in directing EPA to establish NAAQS led to a "natural," "textual" inference that costs should be excluded therefrom. ${ }^{123}$ What keeps this episode so timely today is the path the Court took to reading CAA $\S 109$ (b) to bar cost considerations. The statute erected no explicit barrier to factoring cost into the stringency

117 See, e.g., Bowman Transp., Inc. v. Arkansas-Best Freight Sys., Inc., 419 U.S. 281, 284-86 (1974); State Farm, 463 U.S. at 43.

118 See Chevron U.S.A. v. Natural Resources Defense Council, Inc., 467 U.S. 837 (1984).

119 See, e.g., Mayo Found. for Med. Educ. \& Research v. United States, 562 U.S. 44, 48-58 (2011); City of Arlington v. FCC, 133 S. Ct. 1863, 1867-774 (2013).

120 Cf. Stephen Breyer, Judicial Review of Questions of Law and Policy, 38 ADMIN. L. REV. 363, 379 (1986) ("It is difficult, after having examined a legal question in depth with the object of deciding it correctly, to believe both that the agency's interpretation is legally wrong, and that its interpretation is reasonable.").

121 Whitman v. American Trucking Ass'ns., 531 U.S. 457, 465 (2001).

122 See Whitman, 531 U.S. at 465-67. The principal authority to this effect was the fractured coalition for remanding the rulemaking to OSHA in the Benzene case. See Section 1.1 supra.

123 See Whitman, 531 U.S. at 469-71. 
of its NAAQS. It simply made no mention of cost while at the same time requiring that the NAAQS be "based on"124 a factual document setting out "air quality criteria" which "accurately reflect the latest scientific knowledge useful in indicating the kind and extent of all identifiable effects on public health or welfare."125 Equally suggestive was CAA $\S 108$, which separately requires EPA to communicate techniques and costs of pollution abatement to the states that are charged with attaining the NAAQS. ${ }^{126}$ In Whitman, those suggestions were sufficient to bar costs from consideration. An earlier lower court precedent, Lead Industries Ass'n v. EPA, ${ }^{127}$ reached the same conclusion by a similar path. ${ }^{128}$ The Court in Whitman adopted Lead Industries' interpretation and most of its approach. ${ }^{129}$ Indeed, it went further, stating that "to prevail in their present challenge, respondents must show a textual commitment of authority to the EPA to consider costs in setting NAAQS under $\S 109(\mathrm{~b})(1) .{ }^{\prime \prime 130}$

Notably, though, the Court's Chevron holding that reasonable agency interpretations of ambiguous delegations ordinarily should govern ${ }^{131}$ decisive in another aspect of the Whitman case ${ }^{132}$ - played no role on the factoring of costs. Now this may do little more than confirm that calling something a "factor" is but a placeholder until the number and ranking of all relevant factors is settled. ${ }^{133}$ But the very reasoning in Massachusetts v. EPA ${ }^{134}$ touting the CAA's structured decision making and how

12442 U.S.C. $\$ 7409(\mathrm{~b})(1)$.

12542 U.S.C. $\$ 7408(a)(2)$.

126 See 42 U.S.C. $\$ 7408(b)(1)$.

127647 F.2d 1130 (D.C. Cir. 1980).

128 See Lead Industries, 647 F.2d at 1148-62.

129 See Whitman, 531 U.S. at 464-71. Justice Scalia paid no attention to the CAA's legislative history.

130 Whitman, 531 U.S. at 468.

131 Chevron, U.S.A., Inc. v. Natural Resources Defense Council, Inc., 467 U.S. 837 (1984).

132 See Whitman, 531 U.S. at 481-83 (setting aside as unreasonable EPA's interpretation of Clean Air Act nonattainment provisions under Chevron step two).

133 For example, in Judulang v. Holder, 132 S. Ct. 476 (2011), the Court rejected a long-standing agency policy toward deportable aliens by belittling the weight of the one valid reason for the policy the agency could give: the policy saved it time and money. Cf. Judulang, 132 S. Ct. at 489-90 ("Cost is an important factor for agencies to consider in many contexts. But cheapness alone cannot save an arbitrary agency policy").

134549 U.S. 497 (2007). 
considerations expressly named in the statute generally work to exclude other factors by omission ${ }^{135}$ most assuredly characterized the Whitman opinion. ${ }^{136}$

Contrast that with Entergy Corp. v. Riverkeeper. ${ }^{137}$ There the Court confronted a mandate in the Clean Water Act (CWA) authorizing EPA to set performance standards requiring "that the location, design, construction, and capacity of cooling water intake structures reflect the best technology available for minimizing adverse environmental impact."138 EPA had determined that this mandate permitted it to prepare and use a cost-benefit analysis in setting the standards. ${ }^{139}$ The courts had to decide if that was a permissible or "reasonable" construction of the CWA. As then-judge Sotomayor concluded in an opinion for the Second Circuit Court of Appeals, it was not-or at least EPA's record did not show through evidence or explanation that it had factored costs rationally into its decision. ${ }^{140}$

An oddity of that CWA mandate was a jurisdictional cross-reference to other CWA sections which did expressly name and situate cost as a decision factor. ${ }^{141}$ In the Supreme Court, the cross-reference and the CWA's failure to specify exactly how costs should factor into the standards were decisive in overruling the Second Circuit. It seemed to

135 See Massachusetts, 549 U.S. at 532-35; Richard J. Pierce, Jr., What Factors Can an Agency Consider in Making a Decision?, 2009 MICH. ST. L. REV. 67, 77-79 (2009) (noting Massachusetts' peculiar regard for the CAA's unique alignment of decisional factors).

136 Massachusetts was, in this connection, reminiscent of Union Electric Co. v. EPA, 427 U.S. 246 (1976). Union Electric held that the CAA § 110(a)(2) mandate to EPA that it approve measures in state implementation plans "as may be necessary" to attain applicable NAAQS vested no authority in EPA to reject a plan for being "economically or technologically infeasible." Id. at 256-69.

137556 U.S. 208 (2009).

13833 U.S.C. $\$ 1326($ b).

139 See U.S. EPA, National Pollutant Discharge Elimination System-Final Regulations to Establishment Requirements for Cooling Water Intake Structures at Phase II Existing Facilities, 69 Fed. Reg. 41576, 41650-664 (2004).

140 See Riverkeeper, Inc. v. EPA, 475 F.3d 83, 97-105 (2d Cir. 2007). “[O]n the record before us, it is impossible to tell whether the EPA based its decision on [what it deemed] permissible cost-effectiveness analysis or exceeded its authority by relying impermissibly upon a cost-benefit analysis." Id. at 104 .

141 See 33 U.S.C. § 1326(b) ("Any standard established pursuant to [CWA $\S \S 301$ or 306] applicable to a point source shall require ...."); $c f$. Riverkeeper, Inc. v. EPA, 358 F.3d 174, 186 (2d Cir. 2004) ("That cross-reference is an invitation to look to section 306 for guidance in discerning what factors Congress intended the EPA to consider in determining the 'best technology available."'). 
the Supreme Court majority that "the phrase 'best technology available,' even with the added specification 'for minimizing adverse environmental impact," did not "unambiguously preclude cost-benefit analysis."142 And yet, like his opinion in Whitman, Justice Scalia's majority opinion in Entergy essentially ignored Chevron. The Entergy majority focused on the merest text of the provision: the plausible and necessary inferences from its syntax. In a concurrence Justice Breyer took pains to apply the Chevron framework and demonstrate various contextual ambiguities and the consequent delegation to EPA in filling out the analysis of "best technology available." 143 And for Justices Stevens, Souter, and Ginsburg in dissent, EPA's cost-benefit analysis was just wrong for CWA $\S 316$ (b) because of how "narrow," "skewed," and ultimately inconsistent with the legislation's purposes that analysis had been. ${ }^{144}$

Together, Whitman and Entergy combined dashed whatever hopes persisted for some simple default rules in the weighing of regulation's costs-including the presumption that complex risk regulation statutes that delegate vest the real discretion in the agency. ${ }^{145}$ The Supreme Court has repeatedly showed itself to be deeply divided over whether, why, and how cost shall be factored into regulation and has offered nothing like a simple, general primer for interpreting the Statutes at Large.

There are few assurances to be found in the late personnel changes on the Court. What can be said with confidence is that the Court's arbitrariness review doctrines are and will remain a favored means of challenging agencies' choice of decisional inputs, the investigation and documentation of any relevant quantities involved, and of challenging the legal significance of individuated factors like cost in risk regulation. ${ }^{146}$ The Court's precedents operationalize challenges both to the means/ends rationality and to the policymaking discretion inherent in deciding what form and quantity of evidence can justify risk regulation in the face of

142 Entergy, 556 U.S. at 219-26 (emphasis added).

143 See id. at 231-36 (Breyer, J., concurring in part and dissenting in part).

144 See id. at 238-40 (Stevens, J., joined by Souter \& Ginsburg, JJ., dissenting). EPA encountered great difficulties monetizing the rule's benefits and was quite credibly skewered for having grossly exaggerated its costs. See Doug Kysar, Fish Tales, in REFORMING REgUlatory IMPACT ANALYSIS 190, 192 (Winston Harrington et al. eds., 2009).

145 See, e.g., SunSTEIN, supra note 1 at 191-216.

146 The case studies of Chapters 4, 5, and 6 explore this institutional dimension of weighing costs at length. The US Supreme Court has steadily signaled at least these three distinct aspects of review to the lower federal courts. See Farber, supra note 101 at 91-111. 
any inefficiencies, uncertainties, costs of compliance, etc. ${ }^{147}$ Indeed, reviewing courts rarely need to separate those various elements out in their analysis given the wide ambit contemporary legal systems afford to rooting out official "arbitrariness" of all kinds. The aggregate result defies synthesis given the fact specificity of each case and context. It may be accurate to say that the Supreme Court itself has conducted these reviews in largely deferential tones. ${ }^{148}$ But that past does precious little to predict the future, especially as lower federal courts are now constantly invited to scrutinize regulatory cost estimations and evaluations.

147 See Citizens to Preserve Overton Park v. Volpe, 401 U.S. 402, 408-20 (1971); Bowman Transp., Inc. v. Arkansas-Best Freight Sys., Inc., 419 U.S. 281, 289-94 (1974); Baltimore Gas \& Elec. Co. v. Natural Resources Defense Council, 462 U.S. 87, 97-105 (1983); Motor Vehicle Mfrs. Ass'n v. State Farm Mut. Auto. Ins. Co., 463 U.S. 29, 41-57 (1983); FCC v. Fox Television Stations, Inc., 129 S. Ct. 1800, 1822-24 (2009) (Kennedy, J., concurring in part); Judulang v. Holder, 132 S. Ct. 476, 487-90 (2011).

148 See generally Gersen \& Vermeule, supra note 57. 